\title{
8 Small Shops in Hamburg and Cape Town
}

\author{
A Dialogue between Materiality \\ and Atmosphere
}

\author{
Jannis Androutsopoulos and Ana Deumert
}

\section{Introduction}

This chapter has a history. First conceptualized in the second half of 2019, the idea was that we would focus on small shops, most often called "kiosks" in Hamburg, Germany, and "spazas" in Cape Town, South Africa. The plan was to collect data specifically for this chapter, photograph shop signs, and interview shop owners. At least this was what Ana was planning to do in early 2020. At the time, Jannis had already collected photographic data and was starting the analysis. Then, Covid-19 was declared a pandemic and life, including research, changed fundamentally. South Africa went into a hard lockdown in March 2020, and all possibilities for data collection evaporated within days. As a consequence, we had to be creative in rethinking our chapter. We decided to frame it as a dialogue between two different approaches: a material-semiotic approach to signs grounded in systematic data collection, and an atmospheric approach, which challenges the empirical tenets of much work in sociolinguistics and draws attention to affect, experience, and memory. In this dialogue, the focus of Jannis's discussion and analysis is on the semiotics of shop signs. He adopts a social-semiotic perspective on sign-genres, drawing on a growing, publicly available corpus of photographic data from Hamburg. Ana, on the other hand, reflects, autoethnographically, on her everyday experiences in an inner-city area of Cape Town, where she has lived - with short interruptions - since 1994. She focuses not on the materiality of the shops (and their signs), but on their affective qualities. The central theoretical concept in her discussion is the idea of "atmosphere."

Our chapter is arranged in three main sections. The first section outlines the conceptual basis of our respective contributions, the second section discusses the "small shops" that form the object of our analysis, and the third section reflects on analysis and findings. In the conclusion we examine the potential of these two - methodologically and epistemologically - quite different approaches for a productive dialogue in sociolinguistics. 


\section{Jannis Androutsopoulos and Ana Deumert}

\section{Key Concepts}

\section{Key Concept 1: Genre and Materiality of Signs}

Jannis orients to a semiotic and materialist understanding of linguistic landscape, influenced by geosemiotics, social semiotics, and sociolinguistic approaches to multilingualism (Scollon and Scollon 2003; Jaworski and Thurlow 2010; Pütz and Mundt 2019). His approach centres on signs, understood as materialized and emplaced expressions of communicative action, and sign-genres, understood as functional classes of signs that draw on similar resources and arrangements to accomplish a socially typified communicative act. In the geosemiotic framework of Scollon and Scollon (2003), public signs gain their indexical meanings by emplacement, i.e., their spatial positioning in the world, and by various forms of inscription, including typography and the material surface on which linguistic and pictorial signs are inscribed. Geosemiotics was deeply influential in the transition from so-called distributive approaches to linguistic landscapes, which focus on multilingual signage, to semiotic approaches that underscore the material and discursive construction of all social spaces (Pennycook 2019; Shohamy 2019). This extension has fostered historical, materialist, and ethnographic research, not least an integration of genre theory and analysis into semiotic landscape studies.

The notion of "sign-genres" captures the observation that signs in the semiotic landscape, while each unique in their specific conditions of production, perception, and emplacement, follow lines of similarity in communicative function, referential content, and material-semiotic choices. A genre analysis is an approach that starts from a sign's communicative purpose, rather than its perceivable language(s), and centers on configurations between a sign's discourse function, spatial placement, and semiotic makeup (cf. Stroud and Mpendukana 2012; Järlehed 2018; Reershemius 2018; Androutsopoulos and Chowchong 2021). Genres bundle semiotic resources (including different named languages) in the material realization of a communicative act (e.g., naming a street, identifying a restaurant, regulating public behavior) and thereby provide orientation to the social actors who produce and/or read these signs. Some public signs are entirely standardized, i.e., produced on tightly defined genre templates (e.g., road signs and other types of administrative signage); whereas other signs, especially in the commercial sector, show more variation and fluidity in their generic orientation. In either case, the starting point of a genre analysis of signs is an ethno-category, i.e., a community-based categorization of signs and shops.

Compared to a lumping together of commercial signs, which was common in earlier research, an approach to specific sign-genres enables a "more detailed social semiotic examination" (Huebner 2009, 72) and shifts the focus to semiotic conventions for specific classes of public signs, on the one hand, and the way specific sign producers may strategically distance their signs from such conventions, on the other. In this regard, genre analysis enhances 
granularity in linguistic landscape research (Huebner 2009; Järlehed 2018). A multimodal genre analysis emphasizes the role of semiotic resources, such as color, layout, typography, and material, in the configuration of a signgenre. Even though a multimodal sign-genre analysis does prioritize signs and sign ensembles, it does not rule out an ethnographic approach to the interaction between signs and people in the semiotic landscape. Rather, the two can be viewed as mutually complementing and enriching (Leeman and Modan 2009; Järlehed 2018).

\section{Key Concept 2: Atmospheres}

Ana has long been interested in post-positivist approaches in the social sciences. Non-representational theories are core to such reflections. These are theories (and methodologies) that go beyond representation, focus on the embodiment of experience, and view social life as enacted through a vast array of - ever shifting, flowing, and fluid - everyday practices (Thrift 2008). One concept that has been used in non-representational work is the idea of "atmospheres," a notion that speaks forcefully to "the power of the pre-cognitive" (Vannini 2015, 4; Anderson and Ash 2015). The term "atmosphere" derives from meteorology and refers to a layer of air or gas - atmos - that organizes spatially around bodies and objects, "enveloping" them and "pressing" upon them (Marx 1856, cited in Anderson 2009, 77). Atmospheres, in other words, exert a force and create effects. In everyday speech the word "atmosphere" can be used to express how one experiences social space as a mood and feeling. Thus, we commonly make statements such as: "The atmosphere was serene/tense/happy/caring/hopeful/violent/ peaceful." Or, consider the English idiom: "You could cut the air/atmosphere with a knife." Here felt experience has moved, metaphorically, into the realm of the material; it is intensely physical and indeed "real." Thus, we experience space and interaction not simply visually or acoustically - as landscapes and soundscapes - but also affectively. While we might struggle as scholars to conceptualize atmospheres analytically, the heuristics of everyday language show that atmospheres "are cognitively penetrable, if only on the level of common sense" (Griffero 2014, 12; Sumartojo 2020).

Atmospheres are located in-between the material world and our collective subjectivities; they are pre-dualistic, simultaneously objective and subjective, facts and feelings. As noted by the philosopher Gernot Böhme (2017a, 2):

Atmospheres are quasi-objective, namely they are out there: you can enter an atmosphere and you can be surprisingly caught by an atmosphere. But on the other hand atmospheres are not beings like things; they are nothing without a subject feeling them.

The quasi-objective nature of atmospheres means that they are "producible" (Böhme 2017b, 158). Böhme gives the example of stage design: a 
stage designer aims to create the atmosphere for a play through sound and light as well as objects and their placement in space. Stage designers are trained in creating atmospheres that work, that envelop the senses of audience members in particular ways, drawing them into the mood of the play. Other professions that stage atmospheres are actors and musicians, event planners, advertisers, interior designers, landscapers, and architects. And as teachers and lecturers, we are involved in the production of atmospheres too: creating learning spaces that are safe, comfortable, challenging, and so forth. Even though atmospheres can be produced, there are limits to such interventions. Atmospheres are also inherently unstable, shifting and changing, dynamic and emergent. Sometimes atmospheric shifts occur rapidly, such as when tension is diffused by laughter. They are impossible to control. At other times an atmosphere lingers. It refuses to dissipate and is like a scent that remains. The notion of atmosphere offers us new ways of thinking about the well-established, yet contested, sociolinguistic notion of context; broadly understood as a "frame" that shapes interaction and that, in turn, is created through interaction (Duranti and Goodwin 1992). Drawing on Böhme's notion of "tuned space," Steven Brown and his colleagues (2019) describe atmospheres as "emplaced" and link their study to cultural geography. As a "place-bound approach to affect" (8), atmospheres are of particular interest for studying and understanding semiotic landscapes.

Atmospheres, as noted above, are pre-dualist: they are neither fully subjective nor fully objective; neither fully material nor immaterial. This in-between status speaks to their transformative potential, including the transformation of knowledge production. Tonino Giffero $(2014,108)$, for example, describes atmospheres as being simultaneously "supersubjective" and "superobjective": they are experienced by bodies and articulated by human subjects in language, but they are also a world that is "sensuous on its own terms, generative of its own affects, without invoking human sensibility or language" (Brown et al. 2019, 7). Thus, in the study of atmospheres, we seek to maintain the balance between "feelings simply being projected onto the world (leading to a radical subjectivism) or as intrinsic to the world itself (and therefore a crude materialism)" (Brown et al. 2019, 9).

\section{Small Shops: Hamburg and Cape Town}

\section{Kiosks}

Nouns such as "Kiosk" (kiosk), "Trinkhalle" (drinking hall), and "Späti" ("late-y," a late-hours store) index an ethno-category of shops that are found all over Germany. These nouns are regionally distributed and semantically index specific properties or assortments. The word Kiosk is typical for Hamburg corner shops (Klier 2013: 13, 36-37), Trinkhalle for the Ruhr area, and Späti for Berlin. Their common referent is a local convenience 
store, a small shop that sells goods for everyday consumption on a neighborhood basis. ${ }^{1}$

Academic literature and photographic documentation of German kiosks - by this or other names - offer background on historical and economic, sociological, and anthropological aspects (Kraemer and Osses 2009; Naumann 2003). Kiosks emerge in the second half of the nineteenth century in Germany's industrial areas to supply mineral water to industrial workers, hence early names such as Seltersbude or Wasserhäuschen ([mineral] water booth). In that era, kiosks were often discrete structures inspired by historical kiosk or pavilion architecture. By the end of the nineteenth century, their assortment expanded from non-alcoholic beverages to a variety of products, such as snacks and newspapers, although strictly in small quantities for immediate consumption (Kraemer and Osses 2009, 124). In the 1960s, kiosk opening times were gradually deregulated, creating a niche economy that enabled kiosks to exist in competition with supermarkets. The importance of late opening is reflected in the terms Späti or Spätkauf, specific to Berlin, where many corner shops operate on a 24/7 basis.

Kiosks are typically single-owner or family businesses, often run by immigrant families (Kraemer and Osses 2009, 125; Naumann 2003; Klier 2013). According to Klier's fieldwork (2013) in Berlin, 69\% of Späti owners or managers are of Turkish origin. Kiosks typically serve as sites of urban sociability for residents of a neighborhood or even just a single block of buildings, a purpose especially appreciated by socially isolated or marginalized citizens. Berlin's Spätis support a neighborhood culture of people who meet regularly to hang out and chat, thus they become a "second home for shift-workers, night owls, lonely types, tourists, and students" (Klier 2013, 12 , our translation). For some residents, small talk with a kiosk owner is an enjoyable practice, perhaps even their only chance for a chat throughout the day. Klier also suggests that nine out of ten kiosk owners or managers love their jobs because of the community exchange they afford. Thus, urban kiosks contribute decisively to the maintenance of social interaction in neighborhoods (Klier 2013, 107).

Naumann (2003, 78-95) discusses the material arrangement of Berlin kiosks as an outcome of "total improvisation," where provisional and nonperfect arrangements are the rule. Kiosk signs and interior arrangements are in sharp contrast to the professional advertising and interior design that shape the mainstream retail economy. This non-perfection becomes a core feature of "Kiosk-Kultur" (Naumann 2003, 80). The bricolage character of kiosk storefronts is quite visible on Hamburg's streets as well. A characteristic example from the Hamburg photographic corpus (discussed below) is Figure 8.1.

From a semiotic landscape viewpoint, this façade can be thought of as a semiotic aggregate (Scollon and Scollon 2003) or semiotic assemblage (Pennycook 2019), i.e., a conglomerate of signs by various authors and for various purposes, which draw on a wide range of modal resources and genre patterns. The genre analysis below focuses on primary storefront signs, 


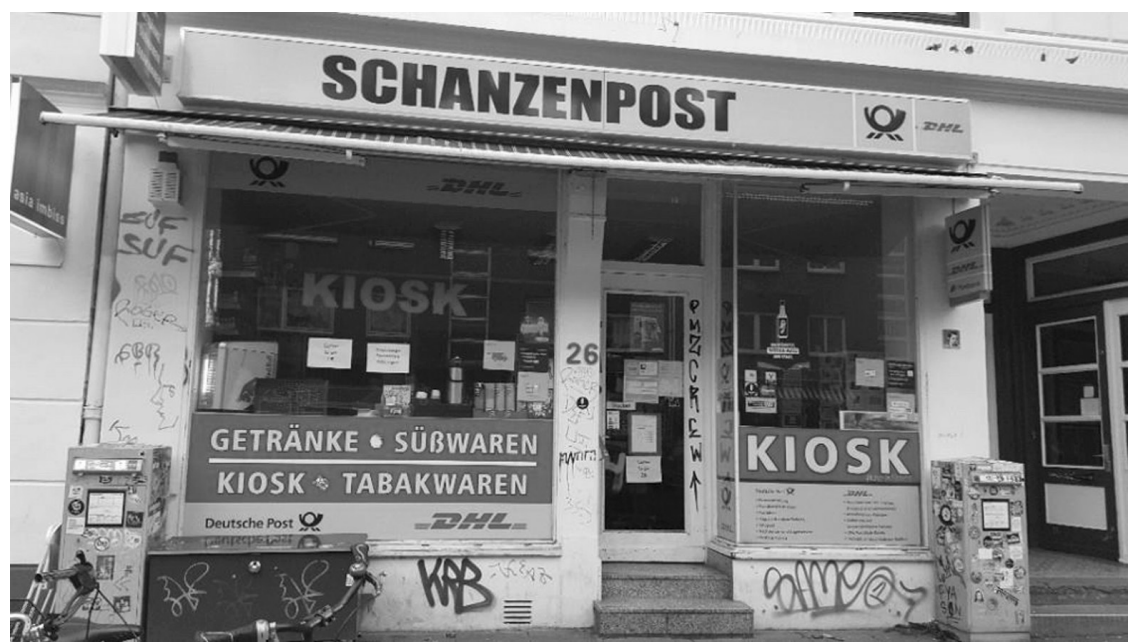

Figure 8.1: Schanzenpost.

i.e., the shop's largest signs, which are usually placed above the entrance (Androutsopoulos and Chowchong 2021). In this example, the primary sign comes in two parts. The first is the large yellow stripe with the store name, Schanzenpost. It is complemented by bylines and side-adverts at the bottom of the storefront window on both sides of the entrance door, which list the goods and services on offer. By virtue of their prominent size and placement, primary signs usually constitute "the most salient point" of the entire storefront, "from where the reading starts" (Scollon and Scollon 2003, 153). Some features of the main sign, notably the word kiosk and the postal service logos, are repeated on the window, perhaps reflecting multiple ownership changes that lead to multiple layers of store signage. In addition, a variety of other signs populate the shop façade: commercial stickers for products, such as Coke or sweets; several notes hand-written by the owner and/or customers; and a lot of tags, which are below the window and on the side columns (though not on the window itself), the latter extending to neighboring surfaces, such as the postbox to the right. This assemblage is typical for urban kiosks in Hamburg. Signs on kiosk shop windows, then, belong to different sign-genres, from which only one is examined below.

These observations tie in well with Neumann's (2003) and Klier's (2013) remarks on the vernacular and improvised material and semiotic culture of kiosk storefronts. Their photographic documentation covers the vernacular literacy that thrives on kiosk storefronts and indoor surfaces, including DIY boards and snack lists, notes to clients, private notes, and so on. Many of these photos feature various non-standard spellings that can be read as traces of their authors' multi-literacies (Blommaert and Dong 2010). 
Naumann's study also covers kiosk names (Naumann 2003, 90-93). While some Berlin kiosks are simply named Kiosk, most have an additional designation that draws on semantic fields such as food (e.g., ExpressImbiss), proper names (e.g., Rosi's, Heidi's, Otto's), and spatial references to urban surroundings, e.g., Am Güterbahnhof ("At the Depot”), Kieler Eck ("Kiel Corner," which is situated on Kielerstrasse). Klier (2013) suggests that in Hamburg's inner-city districts, such as St Pauli, kiosk names often feature the owner's first name or the building's house number or a reference to the neighborhood (Klier 2013, 36). The findings reported below confirm these observations.

\section{Small Shops: Spazas, China Shops, and Trading Stores}

In a different space, South Africa, the legacies of colonialism are ever-present, and the country exhibits one of the highest Gini coefficients in the world ( 0.61 for income inequality and 0.83 for wealth inequality) (Daniels and Khan 2019). Extreme levels of socioeconomic inequality thus shape everyday life in South Africa. These inequalities are grounded in the structures of racial capitalism and the persistent realities of white privilege; they have been exacerbated by Covid-19 (Jain et al. 2020). It is in this broader historical context which has its own atmospheric dimensions - that the discussion is situated.

In her ethnography Raw Life, New Hope (2009), Fiona Ross writes about the local spaza shops, a retail genre that she simply glosses as "small shops" for the reader; no further qualification or explanation is given. By describing them as "small shops," Ross emphasizes size: these shops are easily distinguishable from the large supermarkets and malls that have come to define the retail landscape in South Africa over the past two decades (D'Haese and Huylenbroeck 2005; Crush and Frayne 2018). These developments are not unique to South Africa. The growth of large-scale commercial outlets - often reflecting global brands - is a phenomenon across the world and has put pressure on smaller, often privately owned shops. Yet, as noted by Marc Wegerif (2020) in the context of the Covid-19 pandemic: "small shops" - and other forms of small-scale trading - remain important for ensuring food security and account for between $30 \%$ and $50 \%$ of sales in South Africa (approximately Rand 360 billion per annum). They are thus "small" only in their size, not in their economic impact. Despite their substantial contribution to the economy, they exist on the economic fringe. They are frequently unregistered and operate largely within a cash-based economy (Du Toit 2020; Petersen et al. 2019).

"Spaza" is the name that was given to the small shops that emerged in the urban townships and informal settlements from the 1970s onwards. They were often "survival businesses," allowing for limited economic activity in a political-economic system that sought to exploit Black labor through low wages and discouraged Black entrepreneurship (and indeed any form of Black agency). The presence of spaza shops created alternatives 


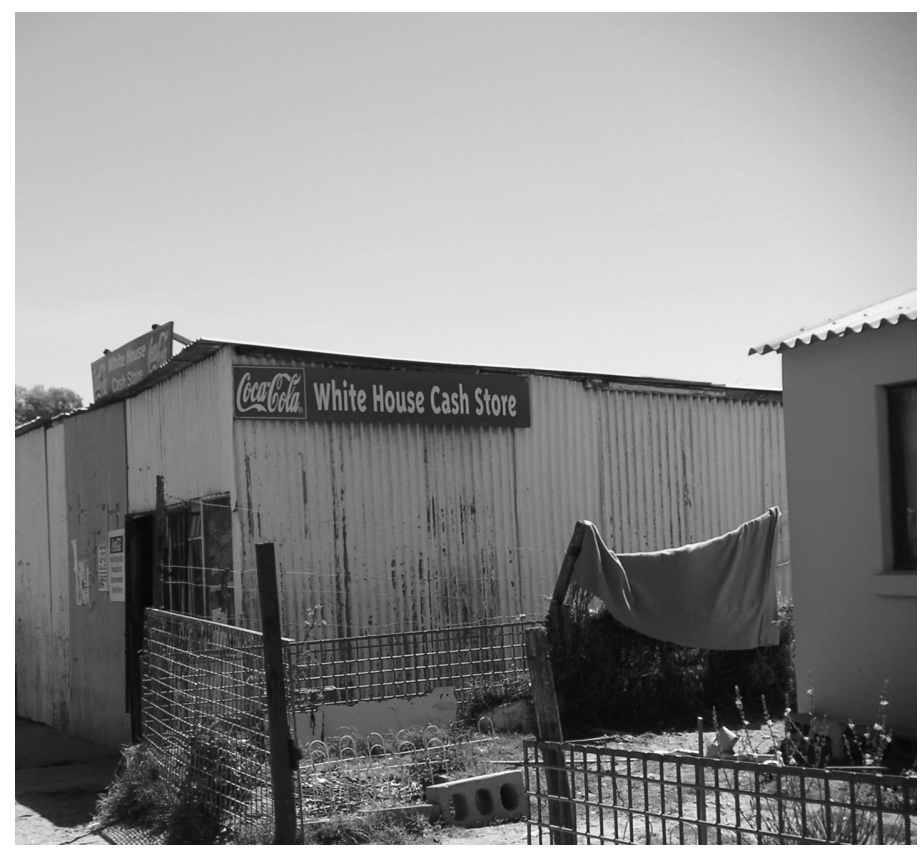

Figure 8.2: Spaza shop in a South African township (2005).

for shopping during the consumer-boycotts of white businesses in the aftermath of the 1976 uprising, and thus disrupted white supremacy and racial capitalism (Spiegel 2005, 193-194). The etymology of the term is assumed to go back to isiZulu "isiphazamisa" (that which causes a hindrance or annoyance) ("isiphazamiso" in isiXhosa) (see Spiegel 2005 for a detailed discussion of possible etymologies and their pitfalls). While historically the term was used to refer to small shops in the township economy, today it is also used to refer to shops in inner-city areas and formerly white suburbs. These inner-city shops were historically run by Greek, Portuguese, or Italian migrants as well as, at least in Cape Town, South Africans of Indian heritage. They were commonly referred to as "cafés." Over the past decade, migrant traders from South Asia and Africa (especially Pakistan, Bangladesh, Ethiopia, and Somalia) have entered the market in large numbers and have become an integral part of the sector (Petersen et al. 2019). The word "spaza" is productive and also can be used metaphorically. For example, it refers to a multilingual hip-hop genre (Mashiyi 2019); it can be used to describe low-quality housing ("spaza houses"), and, apparently, in the 1960s the term indexed low-quality clothing that mimics expensive brands (Spiegel 2005). ${ }^{2}$

The business model of spaza shops - and cafés - can be summarized as follows: (i) unlike malls and large supermarkets, they are located close to 
where people live, rarely more than a five-to-ten minute walk from one's house; (ii) they sell basic food and consumable products in small and affordable quantities (for example, cigarettes can be purchased individually, not in packets); and (iii) they tend to offer credit to their customers. In this way spaza shops respond directly to the often precarious socioeconomic situation of the communities in which they are located. In the urban townships they frequently operate out of metal shipping containers or makeshift structures, and the display of goods is restricted due to limited space. In innercity areas, spaza shops are usually more spacious and tend to be registered businesses.

To round off the discussion of small - and affordable - shops in contemporary South Africa, one should also mention so-called "China shops," which became an integral feature of the local retail landscape over the past twenty years. They often advertise themselves by pointing to the cheap prices they offer (such as, " 5 Rand Store") and sell quite unpredictable mixtures of goods: some food items, household items, cosmetics, electronics, shoes, and clothes (Deumert and Mabandla 2016). And finally, in the rural areas, we find so-called "trading stores." These used to serve villagers in remote communities. Historically, these trading stores were owned and operated by

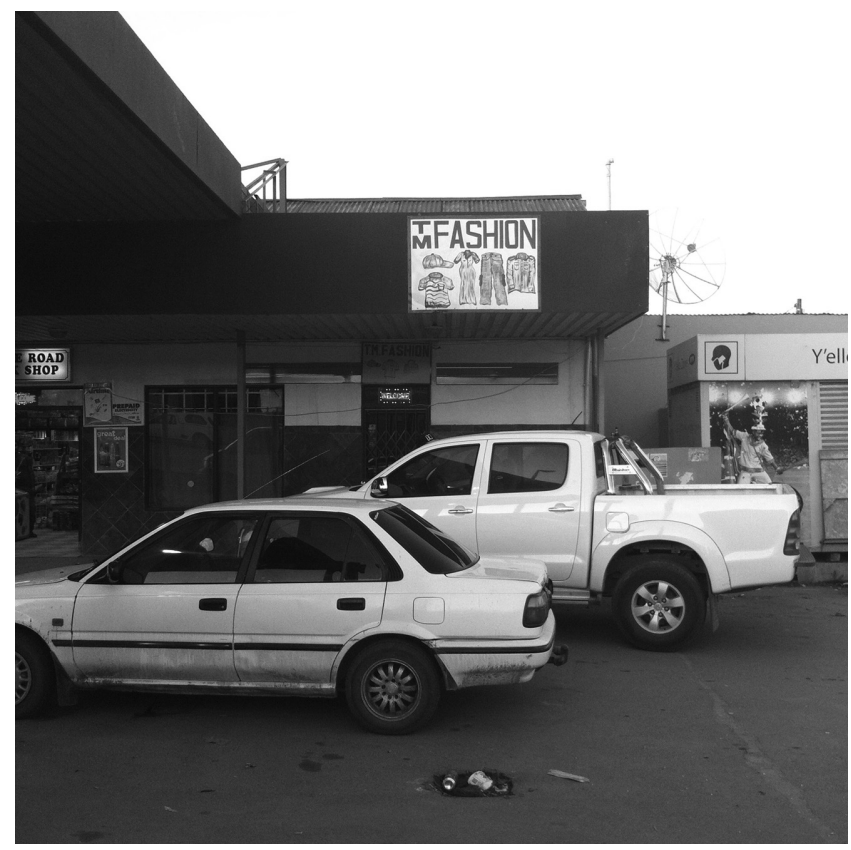

Figure 8.3: A selection of 'small shops': a spaza (left), a China store (middle) and an old phone container (a public phone boot, which contains several phones) which has been turned into a hair salon (specializing in extensions; right; Eastern Cape 2015). 


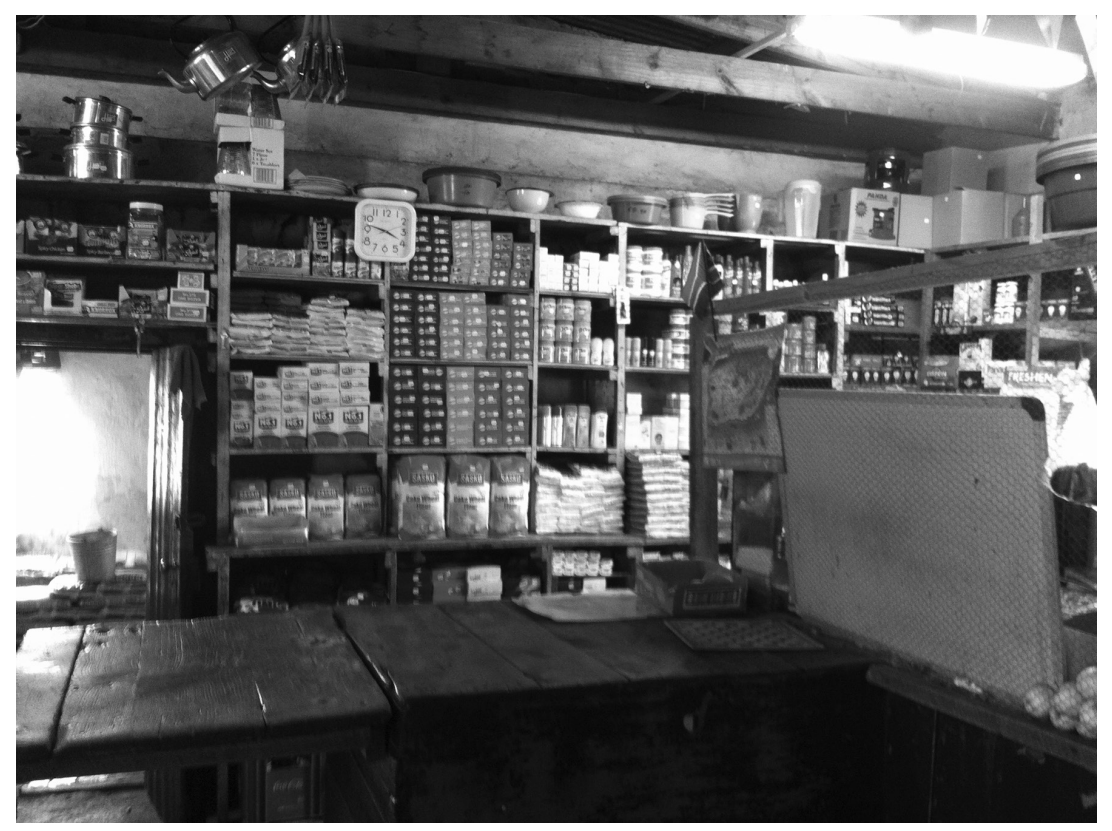

Figure 8.4: Inside a trading store (Eastern Cape 2016).

whites or Indians. Now they are mostly under Black ownership (see Whelan 2011, for an extensive discussion).

The genre of the "small shop" is thus complex, and the three types identified here constitute only a partial typology. There are also butchers and vegetable sellers, taverns and liquor outlets, hair salons and beauty parlors (see also Stroud and Mpendukana 2009).

\section{Analysis and Findings}

\section{Kiosk Signs in Hamburg: Genre Analysis of Primary Signs}

Photographic data for Hamburg was collected with the LinguaSnappHamburg smartphone app, a localized version of the LinguaSnapp application (Gaiser and Matras 2016; Androutsopoulos 2021). This app features a 14-category coding scheme that integrates elements from various linguistic landscape frameworks. Even though it was originally developed for the coding of multilingual signs, almost all of its categories can be applied to any kind of sign. The analysis is based on 64 photographs (collected by mid-March 2020), which represent 48 kiosk signs. ${ }^{3}$ Most of these kiosks appear to be independent shops, with only few being part of a franchise chain, and they are located in inner-city areas as well as close to transportation hubs in outer districts. This corpus seems to represent up to a fifth of all kiosks in Hamburg. ${ }^{4}$ 
The following analysis proceeds in three steps, moving from the composition of primary kiosk signs to their materiality and naming patterns. By funneling down from the entire sign to the semantics of the shop name, the analysis progressively decontextualizes kiosk signs from their contextual emplacement, but at the same time it demonstrates how linguistic and pictorial features of the sign itself link back to its urban surroundings.

Even though no two kiosk signs are identical (unless they are part of a franchise chain), their "family resemblance" traits boil down to three building blocks that occur on most signs in the Hamburg sample: (a) shop name, (b) byline, and (c) side-adverts. Examples are shown in Figure 8.5 (in the predominant landscape format) and Figure 8.6 (in square and portrait format).

The shop name (e.g., Kiosk Steilo, Chaussee Kiosk) is by far the most prominent element on the signs, discussed in detail below. The byline provides additional information on the assortment of products and typically appears adjacent to the shop name. As exemplified in Figure 8.1, the byline can also stand elsewhere on the shop window. However, typical for kiosk facades are Figures 8.5 and 8.6, where the byline stands below or on the side of the shop name or even in-between its constituent parts, as in Kiosk Vering (8.6b). The bylines in the photographic examples vary in terms of the number of listed products (from two to eight), wording, graphic design, and the assortment on offer. What they have in common is a list format with bare nouns and noun phrases and sometimes pictorial signs as well (for example, $8.5 \mathrm{~b}$ and $8.5 \mathrm{c}$ ). Side-adverts (see $8.5 \mathrm{a}$ ) are part of many, though not all, main signs. Very frequently these are the logos of Deutsche Post/ DHL (postal services) or Lotto (state lottery); other common adverts are for beer and soft drinks, often brands based in Hamburg.

Turning to the signs' materiality and design (coloring, typography, pictorial signs, graphic decoration), high-contrast selections for type and background colors predominate. We find yellow type on a red background (or vice versa); white type on a red or green background; and black, blue, red, or green type on a white background. Thus, there are strong and vivid colors, some that are familiar from other domains (e.g., yellow indexes postal service), and there is a lack of pale or shady paint or type. This emphasis on visibility continues at the level of typographic choices. We see
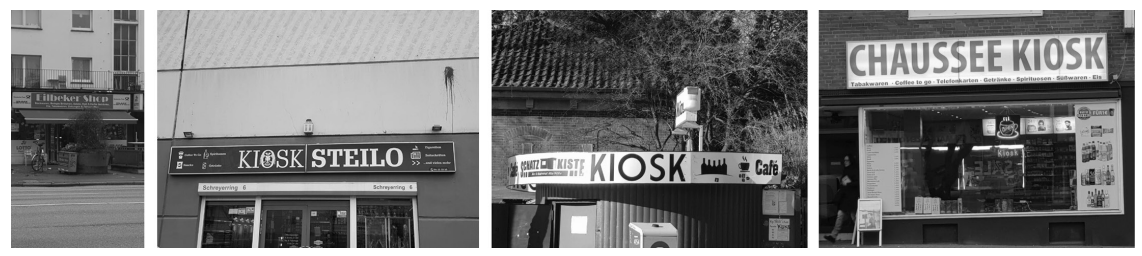

Figure 8.5: Primary storefront signs in landscape format: (8.5a) Eilbeker Shop, (8.5b) Kiosk Steilo, (8.5c) Schatzkiste Kiosk, and (8.5d) Chaussee Kiosk. 

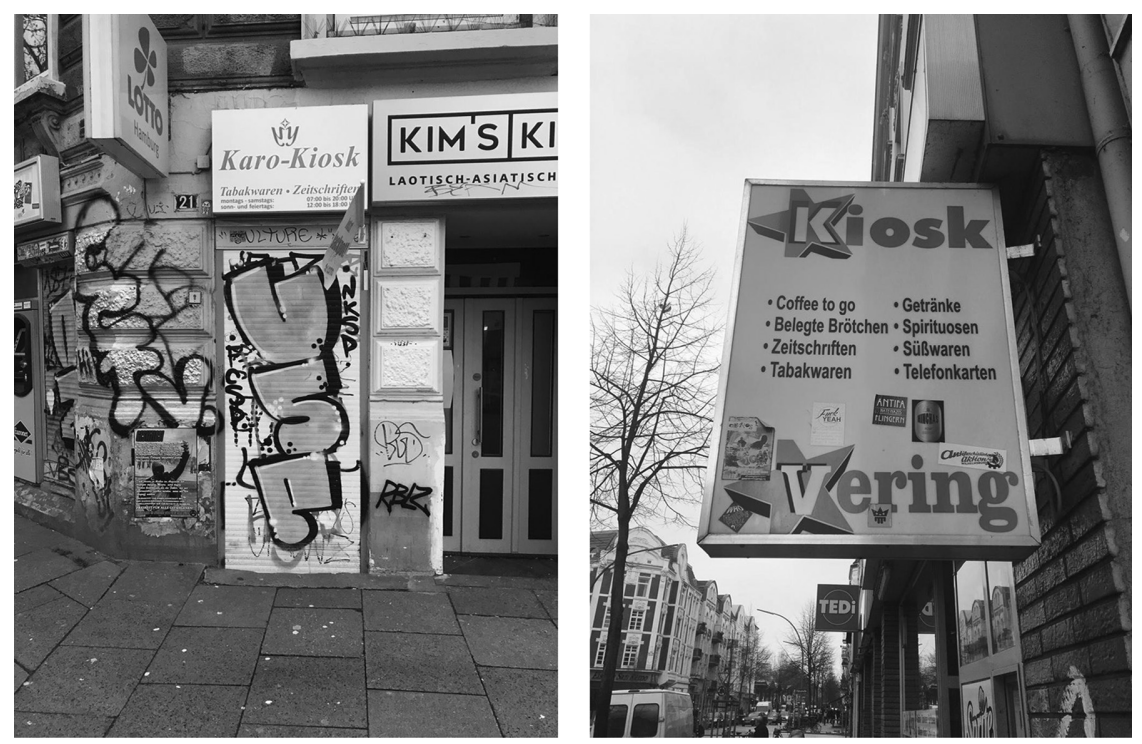

Figure 8.6: Primary storefront signs in portrait format: (8.6a) Karo-Kiosk and (8.6b) Kiosk Vering.

a predominance of sans-serif fonts, a fondness for upper-case and heavy (hence, highly visible) lettering styles, and a complete lack of aestheticized (calligraphic, gothic, or other) typography. The light italics of Karo-Kiosk (Figure 8.6a) are just about the most embellished instance in the corpus. When both upper- and lower-case fonts are used on a single sign, they cast the name and the byline, respectively (for example, 8.5b, 8.5d). Apart from that, there is little typographic variation within a single sign. This is in stark contrast to many commercial signs in Hamburg, where the shop name is typographically set apart by means of size, color, and fonts.

The impression of "no-frills" design continues with pictorial and graphic design. Pictorial elements occur on kiosk signs and are of various kinds. A few signs feature the Hamburg skyline (for example, 8.7d); others include a pictorial illustration of the product assortment. For example, the Schatzkiste sign $(8.5 \mathrm{c})$ features bottles and a cup of hot coffee complemented by the word Café; the shop name is split in two by an icon in the shape of the kiosk itself. Such bimodal redundancy in signification also occurs for all products in the byline of Kiosk Steilo (8.5b), which stands out as one of the most well-designed signs in the corpus. Some side-adverts, too, feature product pictures, e.g., beer or soft drinks. In some cases, a pictorial or graphic element is integrated into the shop's name. For example, Kiosk Vering (8.6b) and Kiosk Susannen (8.7c) feature a red star, perhaps indexing the owner's political stance. Kiosk 87 (8.7a) replaces the letter $O$ with a smiley face, and 
the same letter in Kiosk Steilo (8.5b) hosts an emblematic creature, perhaps a two-headed falcon or eagle. Karo-Kiosk (8.6a) is another instance of a shop logo, which is perhaps the contour of two stylized birds with a star on top. However, these examples are already quite aestheticized in view of several other signs that simply consist of the word Kiosk on a white background. Thus, despite some instances of graphic imagery and pictorial elements - which an ethnographic approach would no doubt illuminate in terms of, for example, the motivation behind image choice or production processes - there is a predominant concentration on straightforward visual design.

Turning to naming patterns, the focus lies on "exophoric indexicality" in kiosk names. In geosemiotics, "exophoric indexicality" is the process by which "reference is made to the world outside the boundaries of the picture" (Scollon and Scollon 2003, 158). All material signs are situated by emplacement, in the sense that they identify a shop or other establishment they are physically fixed or adjacent to. Our interest is on a specific aspect of situated semiotics, whereby signs "reflect the physical environment in which they are placed" (Scollon and Scollon 2003, 163) through reference. This is not forcibly the case for all small shop signs. For example, the sign for 7-Eleven, the global convenience-store chain, is situated by emplacement (i.e., placed in front of the built space that hosts the store), but not by reference, as it does not index its own location. Indeed, the 7-Eleven sign is an instance of decontextualized semiotics (Scollon and Scollon 2003). By contrast, many kiosk signs in Hamburg situate themselves by referencing their surroundings (Figure 8.7).

In a total of $n=48$ kiosk names, $n=22$ feature an exophoric reference to surrounding space, discussed below. Another $n=12$ signs use the word Kiosk itself as a shop name, sometimes in compounds or coordinated nouns without spatial reference, e.g., Lieblings Kiosk (favorite kiosk) or Kiosk \& Blumen (kiosk and flowers). Another $\mathrm{n}=14$ signs follow various other
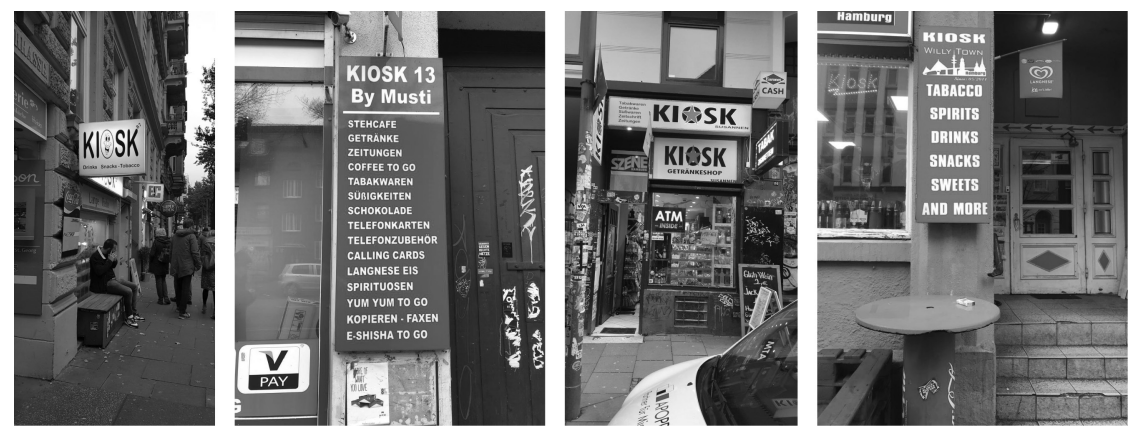

Figure 8.7: Close-ups of names: (8.7a) Kiosk 87, (8.7b) Kiosk Susannen, (8.7c) Kiosk 13 by Musti, and (8.7d) Kiosk Willy Town. 
naming patterns, some including the owner's name (for example, 8.7c). So, the word Kiosk itself is by far the most common shop-name constituent, followed by references to the shop's spatial surroundings. These can be broken down into five patterns of spatial scope, from most to least proximal reference (see examples in Figure 8.7).

The first is when a kiosk name features the house number of its own building: KIOSK 13, KIOSK 39, or Kiosk 97. A second pattern is the reference to the shop's street: Bundes Kiosk, Holsten Kiosk, or Kiosk Susannen. These typically come in abbreviated form, e.g., Bundes Kiosk is on Bundesstrasse. In a third case, the name indexes a nearby public building, e.g., a town hall (Frisches Kiosk am Rathaus) or station (Schatzkiste am Bahnhof Alte Wöhr). Fourth, the name takes up the shop's own neighborhood, e.g., Eilbeker Shop and Kiosk St. Pauli are in the neighborhoods by the same name. Here we find many urban slang designations, e.g., Steilo (for Steilshoop), Willy Town (for Wilhelmsburg), and Karo (for Karolinenviertel). This is a direct parallel to Berlin kiosk names, such as Kotti (at Kottbusser Tor) or Perle-Kiosk (on Perlenberger Str; cf. Naumann 2003, 92). By contrast, there are no kiosks named by the city of Hamburg, a spatial scope that is indexed by pictorial rather than linguistic means (for example, 8.7d).

To conclude, this brief genre analysis shows that the main signs of kiosks, which identify a shop and its product assortment, show generic similarities which reflect the shops' economic affordances just as much as their role in everyday urban life. Three findings must be emphasized. First, kiosks belong to a small number of commercial establishments that directly index their spatial environment. We sometimes see the same patterns on signs of pubs, restaurants, taverns, inns, and similar establishments that constitute urban sites of sociability and everyday interaction. In the case of kiosks, these spatial references reflect a commitment to the local, immediate community, which is at the same time the shops' main clientele and source of income. Some of the signs' side-adverts for local products also contribute to this local indexicality.

Second, kiosk signs are an instance of "no-frills" visual aesthetics. In an affluent Northern city like Hamburg, where commercial signs compete for attention-catching visual design, kiosk signs stand out by virtue of their simplicity. They do not entice passers-by with expensive and complex lettering or with names full of associations. Their visual style is more straightforward, unambiguous, and to the point. This seems directly related to their low-budget conditions of ownership and investment, on the one hand, and their emphasis on the signs' denotative rather than connotative function, on the other. However, "no-frills" does not equate to "no details" or "lack of variation." Had the study considered the entire storefront or the interior store space, it would no doubt have brought to the fore a variety of signage along the lines of Neumann's observations about the improvised literacy of Berlin's small shops. Even the present limitation to main signs brings to the fore a lot of semantic variety and orthographic variation, especially in 
bylines, which reflects the individual, improvised, non-corporate character of small shops.

Finally, kiosks are a counterexample to the assumption of a straightforward display of heritage languages in the semiotic landscape. Given the very high number of migrant kiosk owners in Hamburg, the overwhelming absence of languages other than German on the main signs is in need of explanation, which I suggest is to be sought precisely in the shops' economic conditions: they aim to be maximally inclusive and do so in German. Kiosk signs thus orient to the language the audience is assumed to understand rather than the language(s) sign producers themselves prefer to speak. However, this does not rule out that kiosks, as spaces of urban sociability, offer opportunities for diverse languaging practices among their patrons.

\section{Small Shops in Cape Town: Atmospheric Resonances}

How does one start to write about atmospheres at a time when we are socially distant and often isolated from one another? At a time when many avoid social contact even after the formal Covid-19 lockdown was lifted? Given that atmospheres are collectively experienced, how can one write about them without speaking to others, without listening to their experiences? It seems that the only approach one can adopt in such a moment is autoethnography, reflecting on oneself, one's reactions and feelings as one enters the assemblages that constitute a "shop": people, items of consumption, signs and shelfs, counters and decorations, light, sound, and smells (for a discussion of social life as assemblage, see Latour 2005). Autoethnography, which "seeks to disrupt the binary of science and art" (Ellis, Adams and Bochner 2011), sits uneasily within a section called "analysis and findings." This formulation articulates standardized "scientific" discourse and is at odds with the narrative impetus of ethnographic writing, which foregrounds the importance of emotion and personal voice (Stroud and Jegels 2014).

Autoethnography raises the all-important question of positionality: how does my being-in-the-world shape my perspective-on-the-world? How does my "I" - embodied and historically situated, yet also dynamic and of mobile fragmentation - find itself entangled with the objects and subjects of the semiotic landscape? And how do I move from my first-order experience to a second-order narrative (on first-/second-order categories, see Pablé and Hutton 2015)? Does my positionality remain stable across experience and narrative? Our beings-in-the-world are multiple and intersectional. There is race and age, gender and class, but also our politics and the dreams and hopes that we have not only for ourselves but also for the worlds that surround us. I grew up in West Germany (white, female, middle-class-with-workingclass-intergenerational-roots-and-East-German-family) and migrated from north to south in my twenties, settling in the same neighborhood where I still live today. My whiteness bestows various forms of privilege and advantage on me, yet my foreignness can bring with it experiences of non-belonging, of 
being-outside-looking-in. This, however, is softened by my South African family, which keeps me grounded and connected to local struggles. Yet, as I write these brief notes on my positionalities and relationalities, I ask myself: What matters and what doesn't? Where do I stop? I will stop here, because paying attention to positionality does not mean that we resurrect the Cartesian self-contained subject in all its glory. Borders are always fuzzy, grey zones will remain, and some knowledges are tacit and defy representation (Simandan 2019). Once we accept that all knowledge is subject to error and that the immediacy of experience does not establish a truth regime, then autoethnography is interesting not so much for what it tells, but perhaps even more so for the silences that it leaves (MacFarlane 2020).

Before turning to the supersubjective/superobjective entanglements of the semiotic landscape (and its atmospheres), let me provide a bird's-eye view of the many small shops in the neighborhood. They carry names such as Rainbow Supermarket, Smokers Choice Mini Market, Mini Market and Tobacco Bar, Super Save Store, Lifestyle Market, Seven Star Superette, and Superette \& Coffee Shop. ${ }^{5}$ Even though the terms "spaza" and "café" are colloquially used to refer to these shops (at least in our household), their self-descriptors are quite different: "supermarket," "superette," "mini market," "store." Thus, unlike in Germany, the semantic field is broad and multiple. Seeing the word "superette" on the shop sign suggests that the owner is most likely from South Asia or Somalia; referring to them as spazas - or cafés - articulates familiarity with the local, South African shopping landscape. While the names on the signs differ, the shops are architecturally and aesthetically united. Signs are painted in bright red, and the Coca Cola logo is omnipresent (see also Figure 8.1). Indeed, red is the color of the shops, announcing them to potential customers. In some cases, it is not just the sign that is red, but the entire shopfront is painted red. Occasionally bright pink and green join the design. Spaza shops stand out in the urban landscape - they too, like the kiosks discussed by Jannis, strive for visibility. They appear cheerful, articulating a sense of plenty, such as a sign outside the Superette \& Coffee Shop: "FRESH FRUITS, MILK \& BREAD, COOL DRINKS, CHOCOLATES, CHIPS, CIGARETTES, AIRTIME, ELECTRICITY AND MANY MORE!!!” Yet, spaza shops carry different meanings in different places. Stroud and Jegels (2014) and Stroud, Peck, and Williams (2019) discuss spaza shops in the same city, but in a different space. They focus not on a formerly white, working-class, inner-city neighborhood, but a marginalized township on the Cape Flats. In this context the shop serves as an index of the poverty that has devastated the community. It is a survival business that one turns to only when everything else fails. In their interpretation (drawing on narrated walking) the presence of a spaza shop is "a sign to make ends meet," a "sorrow-laden lament about the large number of unemployed people in the township" (Stroud, Peck and Williams 2019, 9-10). By contrast, the shops that I listed above are not survival businesses in this sense. Rather, they are sustainable commercial enterprises that 
are located in a marginal, yet thriving, migrant economy. Thus, spazas are not the same - different spaces in the city articulate the genre differently and are read differently by those who enter or pass by them.

Wee $(2016,108)$ positioned affect firmly within the study of linguistic landscapes. He writes:

[W] may have to appreciate that there may well be a relatively broad spectrum of allowable emotions associated with any landscape as well as dispositions that are not easily categorized as emotions.

(see also Peck, Stroud and Williams 2019)

Wee $(2016,109)$ links affect explicitly to atmosphere: "The notion of affect therefore is useful when we want to look at the role that language plays in encouraging or creating a particular ambience/atmosphere." However, it is not just language that creates atmospheres, but rather - as noted above - social assemblages. Brown and his colleagues $(2019,10)$ emphasize this when they write:

Atmospheres exist between subjects and objects. They depend on both the features of the environment and that of the person who engages with them, but cannot be reduced to either.

To capture these subject-object relations, let me start with an event, a fragment taken out of the flow of a day. And as I do so, I am acutely aware of the representational pitfalls of narration and discourse. Yet, I will try, because in a book, words and text are what we have.

It is a Thursday during Covid-19 lockdown, day 251 in South Africa. We are now at level 1, which allows quite a bit of movement, provided that physical distancing and masks are in place. After several weeks of low infection rates, we are witnessing a new surge, and there is growing concern about a new wave. I have been working at home for 251 days, and like many others I limit my movements and interactions as much as possible. Yet not everything can be done at home, without interaction. A friend texts me: she would like to return some books she had borrowed from me before lockdown. We meet centrally, at a well-known landmark in the neighborhood, opposite the village green. As our offices remain closed and visits to private homes are discouraged, public places have become meeting spaces, offering opportunities for fleeting sociabilities. It is strange moment: we are in a pandemic and never know when, and if, we will see each other again. As I walk back home, I feel oddly emotional. It is warm, no wind, the beginning of summer. I pass one of the spaza shops in the neighborhood. The shop is located next to the train station, adjacent to a small, informal market where food, coffee, spices, and other goods are sold. The only traffic is people walking; the road is for pedestrians only. A hand-written sign above the area designates it as a "LIFESTYLE MARKET," and the spaza shop, located just outside the market, uses this name as well. As I approach the area, I hear 
music playing, jazz-fusion with an African beat, a car hoots, and a tall man, who is buying sweets for his grandson at the spaza shop, complains loudly about the prices. My feelings shift, my bodily practice shifts: I listen; I walk slower; I look at the shops; I greet, talk, and buy something small to take home. I am back in the world, my emotions no longer spinning inside my head/mind, but responding and responsive to what I see, hear, and smell.

What was it about the atmosphere of the space that changed my mood from somber and a little sad to cheerful and hopeful? The space can be described as constituting an "affective regime" (in the sense of Wee 2016). Passers-by are welcomed by hand-written signs that are located on the pavement. The signs invite them to leave the road and enter the market; they are meta-affective signs, articulating an affective stance that seeks to influence the mood of those walking past. The first building is the "HOUSE OF FATCAKES," which is painted in bright green. Fat cakes are a local type of doughnut. Next to the shop is a hand-painted sign for "IVY'S KITCHEN. The Home of African Food with a Smile." Another colorful sign announces a spice shop: "WOW!!!!AT THE SPICE SHOP!! SPICES. SPICES. ALL FOR YOU. COME TRY IT, AT ONLY R8!! NO JOKES!!” Yet another sign leans against the iron fence that surrounds the space: "MAMMA CHIPS. Come inside the gate. Hot Chips R15 - Regular R15." There are more signs written on moveable blackboards: "LOOK AT THIS!! FOR SUMMER!! ROOI KRANS BRAAI WOOD CHARCOAL AND FIRE LIGHTERS!! FOR SALE!!" and "WOW! SPICE SHOP - SPECIAL COMBO R10 COFFEE R5 - HOT CHOC R5 - CAPPUCINO R5 - MILO R5 - CAN'T BE!! FOR R5?" There are bold capital letters, some emphasized with red chalk and exclamation marks. There is exuberance in these hand-drawn signs, they "'radiate" affect (Brown et al. 2019); yet they are also ephemeral as the chalk can be washed off from the blackboard by just one rain shower.

Just outside the market is the spaza shop, displaying a limited number of goods on makeshift shelves in a dimply lit space. Painted in bright red, with pink shutters, the shop displays the color of Coca Cola, but not the sign. Instead, the shopfront advertises bread, a basic staple food, a necessity of life, not a luxury: "SASKO SOLD HERE." This is the only spaza shop in the neighborhood that is secured by wire. One can hardly see inside the dark interior, and money and goods are handed through a small window. This might appear "unwelcoming"; yet there is nothing unwelcoming about it to those who visit the spaza shop regularly, stopping to buy something to drink or exchange greetings and goodbyes. The bright colors are attractive, and a small roof constructed out of corrugated iron protects waiting customers from sun and rain. The latter, a sign of care and sociality, allows people to linger and talk. Similarly, tables and chairs invite customers to sit down to drink their coffee or enjoy some food.

I have described the affective regime of the market, including the spaza shop, as welcoming, inviting potential customers with good cheer. It is a 
relaxed and comfortable space (which stands in stark contrast to the highly regimented affective regime described by Wee 2016). Yet there is more. The space - and the materiality of its sign objects - reflects what Stroud and Mpendukana $(2009,373)$ described as "sites of necessity": "The signage is manually produced ... with relatively modest investment and fashioned out of materials that don't weather well." The businesses work with minimal profit margins, and although they survived the hard lockdown between March and June 2020, they remain fragile and precarious. And thus, alongside the welcoming atmosphere, there is another atmosphere of precarity and marginalization - pressing against the cheerful signs, the makeshift architectures of care, and the bright colors and exuberant exclamation marks (on atmospheres as multiple, see Anderson and Ash 2015). Located at a distance from the main shopping area in the neighborhood, these shops cater mainly for those who walk and/or take public transport; that is, Black working-class people with limited incomes living in communities where high unemployment is endemic. Next to the market is a grim reminder of precisely these inequalities. In the shadows, under the bridge, is a space where homeless people store their belongings and sleep at night. The presence of English on the signs also speaks to these violent inequalities: the fact that in a multilingual country the former colonial language, a minority language, has become not only a sign of affluence and upward mobility, but also a lingua franca in "sites of necessity" (on English in South Africa, see Kamwangamalu and Tovares 2016).

In this section, I tried to find a balance between the autoethnographic narration of my own experiences and feelings as I pass through the semiotic landscape of my neighborhood, and the recognition that the world is also "sensuous on its own terms, generative of its own affects, without invoking human sensibility or language" (Brown et al. 2019, 7). Seeing the semiotic landscape as an assemblage of subjects, objects, and affects recognizes the importance of materialities, while also going beyond them by paying attention to the affects they engender.

\section{Conclusion}

In the introduction to this chapter, we positioned our reflections as a dialogue between different spaces and different approaches. We dubbed them "material" and "atmospheric." We asked ourselves: How can the two approaches be combined? In some ways their linkages are obvious. Both approaches deal with space. Space as seen and documented, and space as experienced and felt. In a sense, our dialogue takes up two dimensions of space as conceived by Henri Lefebvre, i.e., "perceived space" and "lived space" (Lefebvre 1991; Wu, Techasan and Huebner 2020). Jannis's interest in the genre and materiality of kiosk signs is an exercise in the study of perceived space, whereas Ana's turn to atmospheric thinking brings up space as something that happens, which we can experience. At the same time, 
our argument is one of methodological multitude and diversity. We suggest that it is not necessary to decide on using only one approach. Instead, we can combine and mix different methods and theoretical perspectives, and our analyses are the richer for this. The discussion in this chapter has illustrated the potential complementarity of these approaches. Signs can be studied as material artefacts whose semiotic choices index various aspects of their spatial and social context; signs are also part of the spatial design of shops and urban spaces, and as such they create atmospheres and affect our experiences, interacting with sounds, smells as well as our own histories.

\section{Notes}

1 The photography collection by Kraemer and Osses (2009) features shop signs with the nouns Trinkhalle (drinking hall), Verkaufshalle (selling hall), Bude (shack), and Kiosk. Klier's Berlin photographs (2013, 18-21) show designators such as Mini Markt and City Kiosk alongside Spätkauf.

2 Today, such clothing is referred to as Fong Kong, indicating the rise of Chinese clothing that imitates brands.

3 All photos can be retrieved on the LinguaSnappHamburg online map at https:// map.linguasnapp.uni-hamburg.de/table?title=kiosk

4 A city of Hamburg inventory (www.hamburg.de/branchenbuch/hamburg/1023 8343/n0/) lists 215 kiosks, and the German "yellow pages” (www.gelbeseiten.de/ Branchen/Kiosk/Hamburg) feature 238 kiosks in Hamburg. However, I suspect the total number might be higher.

5 Several of the shops integrate the name of the neighborhood on the sign. These references have been deleted for ethical reasons.

\section{References}

Anderson, B. 2009. "Affective Atmospheres." Emotion, Space and Society 2: 77-81. Anderson, B., and J. Ash. 2015. "Atmospheric Methods." In Non-Representational Methodologies: Re-Envisioning Research, edited by P. Vannini, 34-51. London: Routledge.

Androutsopoulos, J. 2021. "Linguistic Landscape - Forschung mit dem Smartphone: Möglichkeiten und Grenzen der Webapplikation LinguaSnappHamburg." In Linguistic Landscapes im deutschsprachigen Kontext, edited by E. Ziegler and H. F. Marten, 39-63 Frankfurt A.M.: Lang.

Androutsopoulos, J., and A. Chowchong. 2021. "Sign-Genres, Authentication, and Emplacement: The Signage of Thai Restaurants in Hamburg, Germany." Linguistic Landscape, 7: 204-234.

Blommaert, J., and J. Dong. 2010. "Language and Movement in Space." In Handbook of Language and Globalization, edited by N. Coupland, 366-385. Malden, MA: Wiley-Blackwell.

Böhme, G. 2017a. The Aesthetics of Atmospheres. London: Routledge.

Böhme, G. 2017b. Atmospheric Architectures. The Aesthetics of Felt Spaces. London: Bloomsbury.

Brown, S. D., A. Kanyeredzi, L. McGrath, P. Reavey, and I. Tucker. 2019. "Affect Theory and the Concept of Atmosphere." Distinktion: Journal of Social Theory 20: 5-24. 
Crush, J., and B. Frayne. 2018. “The 'Supermarketization' of Food Supply and Retail. Private Sector Interests and Household Food Security." In Food and Nutrition Security in Southern African Cities, edited by B. Frayne, J. Crush, and C. McCordic. London: Routledge.

Daniels, R. C., and S. Khan. 2019. Household Balance Sheets in South Africa. Cape Town: SALDRU. Working Paper 248. http://opensaldru.uct.ac.za/bitstream/ha ndle/11090/970/2019_248_Saldruwp.pdf (accessed 30 October 2020).

Deumert, A., and N. Mabandla. 2016. "Globalization Off the Beaten Track Chinese Migration to South Africa's Rural Towns." In Multilingualism in the Chinese Diaspora Worldwide, edited by Li Wei, 15-31. London: Routledge.

D'Haese, M., and G. Van Huylenbroeck. 2005. “The Rise of Supermarkets and Changing Expenditure Patterns of Poor Rural Households Case Study in the Transkei Area, South Africa." Food Policy 30: 97-113.

Du Toit, A. 2020. "South Africa's Spaza Shops: How Regulary Avoidance Harms Informal Workers." The Conversation, 24 February 2020. https://theconversat ion.com/south-africas-spaza-shops-how-regulatory-avoidance-harms-informalworkers-130837 (accessed 30 October 2020).

Duranti, A., and C. Goodwin, eds. 1992. Rethinking Context - Language as an Interactive Phenomenon. Cambridge: Cambridge University Press.

Ellis, C., T. E. Adams, and A. P. Bochner. 2011. "Autoethnography: An Overview." Historical Social Research/Historische Sozialforschung 36: 273-290.

Gaiser, L., and Y. Matras. 2016. "The Spatial Construction of Civic Identities: A Study of Manchester's Linguistic Landscapes." http://mlm.humanities.manchest er.ac.uk/publications (accessed 30 October 2020).

Griffero, T. 2014. Atmospheres: Aesthetics of Emotional Spaces. Farnham: Ashgate.

Huebner, T. 2009. "A Framework for the Linguistic Analysis of Linguistic Landscapes." In Linguistic Landscape: Expanding the Scenery, edited by E. Shohamy and D. Gorter, 70-87. New York and London: Routledge.

Jain, R., J. Bulender, R. Zizzamia, and I. Bassier. 2020. The Labour Market and Poverty Impacts of COVID-19 in South Africa. Cape Town: SALDRU. Working Paper 264. http://www.opensaldru.uct.ac.za/bitstream/handle/11090/980/2020 _264_Saldruwp.pdf (accessed 30 October 2020).

Järlehed, J. 2018. "Genre and Metacultural Displays: The Case of Street-Name Signs." Linguistic Landscape 3, no. 3: 286-305.

Jaworski, A., and C. Thurlow. 2010. "Introducing Semiotic Landscapes." In Semiotic Landscapes: Language, Image, Space, edited by A. Jaworski and C. Thurlow, 1-40. London and New York: Continuum.

Kamwangamalu, N., and A. Tovares. 2016. "English in Language Ideologies, Attitudes, and Educational Practices in Kenya and South Africa." World Englishes 35: 421-439.

Klier, C. 2013. Der Späti. Eine Ortsuntersuchung in Berlin. Berlin: Berlin Story Verlag.

Kraemer, B., and D. Osses. 2009. Die Bude: Trinkhallen im Rubrgebiet. Essen: Klartext.

Latour, B. 2005. Reassembling the Social. Oxford: Open University Press.

Leeman, J., and G. Modan. 2009. "Commodified Language in Chinatown: A Contextualized Approach to Linguistic Landscape.” Journal of Sociolinguistics 13, no. 3: 332-362.

Lefebvre, H. 1991. The Production of Space. Cambridge, MA: Blackwell. 
MacFarlane, K. 2020. "Negative Research: Sonic Methods in Geography and Their Limits." The Professional Geographer 72, no. 2: 297-308.

Mashiyi, S. A. 2019. Spaza Hip Hop in the Townships of Khayelitsha. Unpublished MA Dissertation, University of the Western Cape. http://etd.uwc.ac.za/xmlui/han dle/11394/6966 (accessed 30 October 2020).

Naumann, E. 2003. Kiosk: Entdeckungen an einem alläglichen Ort. Vom Lustpavillon zum kleinen Konsumtempel. Marburg: Jonas.

Pablé, A., and C. Hutton. 2015. Signs, Meaning and Experience. Integrational Approaches to Linguistics and Semiotics. Berlin: Walter de Gruyter.

Peck, A., C. Stroud, and Q. Williams, eds. 2019. Making Sense of People and Place in Linguistic Landscapes. London: Bloomsbury.

Pennycook, A. 2019. "Linguistic Landscapes and Semiotic Assemblages." In Expanding the Linguistic Landscape, edited by M. Pütz and N. Mundt, 75-88. Bristol: Multilingual Matters.

Petersen, L., C. Thorogood, A. Charman, and A. Du Toit. 2019. What Price Cheap Goods? Survivalists, Informalists and Competition in the Township Retail Grocery Trade. Cape Town: University of the Western Cape, Institute for Poverty, Land and Agrarian Studies. PLAAS Working Paper 59.

Pütz, M., and N. Mundt, eds. 2019. Expanding the Linguistic Landscape. Bristol: Multilingual Matters.

Reershemius, G. 2018. "Lamppost Networks: Stickers as a Genre in Urban Semiotic Landscapes." Social Semiotics 29, no. 5: 622-644.

Ross, F. C. 2009. Raw Life, New Hope: Decency, Housing and Everyday Life in a Post-Apartheid Community. Cape Town: University of Cape Town Press.

Scollon, R., and S. W. Scollon. 2003. Discourses in Place. Abingdon, UK: Taylor $\&$ Francis.

Shohamy, E. 2019. "Linguistic Landscape after a Decade: An Overview of Themes, Debates and Future Directions." In Expanding the Linguistic Landscape, edited by M. Pütz and N. Mundt, 25-37. Bristol: Multilingual Matters.

Simandan, D. 2019. "Beyond Haraway? Addressing Constructive Criticisms to the 'Four Epistemic Gaps' Interpretation of Positionality and Situated Knowledges.” Dialogues in Human Geography 9: 166-170.

Spiegel, A. 2005. "Refracting an Elusive South African Urban Citizenship: Problems with Tracking Spaza." In Limits to Liberation after Apartheid: Citizenship, Governance and Culture, edited by S. L. Robins, 190-205. Oxford: James Currey.

Stroud, C., and D. Jegels. 2014. "Semiotic Landscapes and Mobile Narrations of Place: Performing the Local." International Journal of the Sociology of Language 228: 179-199.

Stroud, C., and S. Mpendukana. 2009. "Towards a Material Ethnography of Linguistic Landscape: Multilingualism, Mobility and Space in a South African Township." Journal of Sociolinguistics 13: 363-386.

Stroud, C., and S. Mpendukana. 2012. "Material Ethnographies of Multilingualism: Linguistic Landscapes in the Township of Khayelitsha." In Multilingualism, Discourse, and Ethnography, edited by S. Gardner and M. Martin-Jones, 149162. London: Routledge.

Stroud, C., A. Peck, and Q. Williams. 2019. "Introduction: Visceral Landscapes (The Inside Story)." Sociolinguistic Studies 13: 7-14. 
Sumartojo, S. 2020. “Thinking Place Atmospherically.” In The Routledge Handbook of Place, edited by T. Edensor, A. Kalandides, and U. Kothari. London: Routledge.

Thrift, N. 2008. Non-Representational Theory: Space, Politics, Affect. London: Routledge.

Vannini, P. 2015. "Non-Representational Research Methodologies: An Introduction." In Non-Representational Methodologies: Re-Envisioning Research, edited by P. Vannini, 1-18. London: Routledge.

Wee, L. 2016. "Situating Affect in Linguistic Landscapes." Linguistic Landscape 2: 105-126.

Wegerif, M. C. 2020. “'Informal' Food Traders and Food Security: Experiences from the COVID-19 Response in South Africa." Food Security 12: 797-800.

Whelan, D. 2011. Trading Lives: The Commercial, Social and Political Communities of the Zululand Trading Store. Doctoral dissertation, SOAS, University of London. https://eprints.soas.ac.uk/12772/1/Whelan_3281.pdf (accessed 30 October 2020).

Wu, H., S. Techasan, and T. Huebner. 2020. "A New Chinatown? Authenticity and Conflicting Discourses on Pracha Rat Bamphen Road." Journal of Multilingual and Multicultural Development, 41(9):794-812. doi: 10.1080/0143 4632.2020.1746318 